\title{
The Ceramic Sherd Assemblage from the C. D. Marsh Site (41HS269) in Harrison County, Texas
}

Timothy K. Perttula

Heritage Research Center, Stephen F. Austin State University

Mark Walters

Heritage Research Center, Stephen F. Austin State University

Patti Haskins

Follow this and additional works at: https://scholarworks.sfasu.edu/ita

Part of the American Material Culture Commons, Archaeological Anthropology Commons, Environmental Studies Commons, Other American Studies Commons, Other Arts and Humanities Commons, Other History of Art, Architecture, and Archaeology Commons, and the United States History Commons

Tell us how this article helped you.

This Article is brought to you for free and open access by the Center for Regional Heritage Research at SFA ScholarWorks. It has been accepted for inclusion in Index of Texas Archaeology: Open Access Gray Literature from the Lone Star State by an authorized editor of SFA ScholarWorks. For more information, please contact cdsscholarworks@sfasu.edu. 


\section{The Ceramic Sherd Assemblage from the C. D. Marsh Site (41HS269) in Harrison County, Texas}

\section{Creative Commons License}

\section{(c) (1) \&}

This work is licensed under a Creative Commons Attribution-NonCommercial 4.0 International License 


\title{
The Ceramic Sherd Assemblage from the C. D. Marsh Site (41HS269) in Harrison County, Texas
}

\author{
Timothy K. Perttula, Mark Walters, and Patti Haskins
}

\section{INTRODUCTION}

The C. D. Marsh site (41HS269) is an ancestral Caddo settlement and cemetery on Eight Mile Creek, a southwestward-flowing tributary to the Sabine River in southeastern Harrison County, Texas (Figure 1). It is on an alluvial terrace about $1.6 \mathrm{~km}$ from the confluence of Eight Mile Creek and the Sabine River.

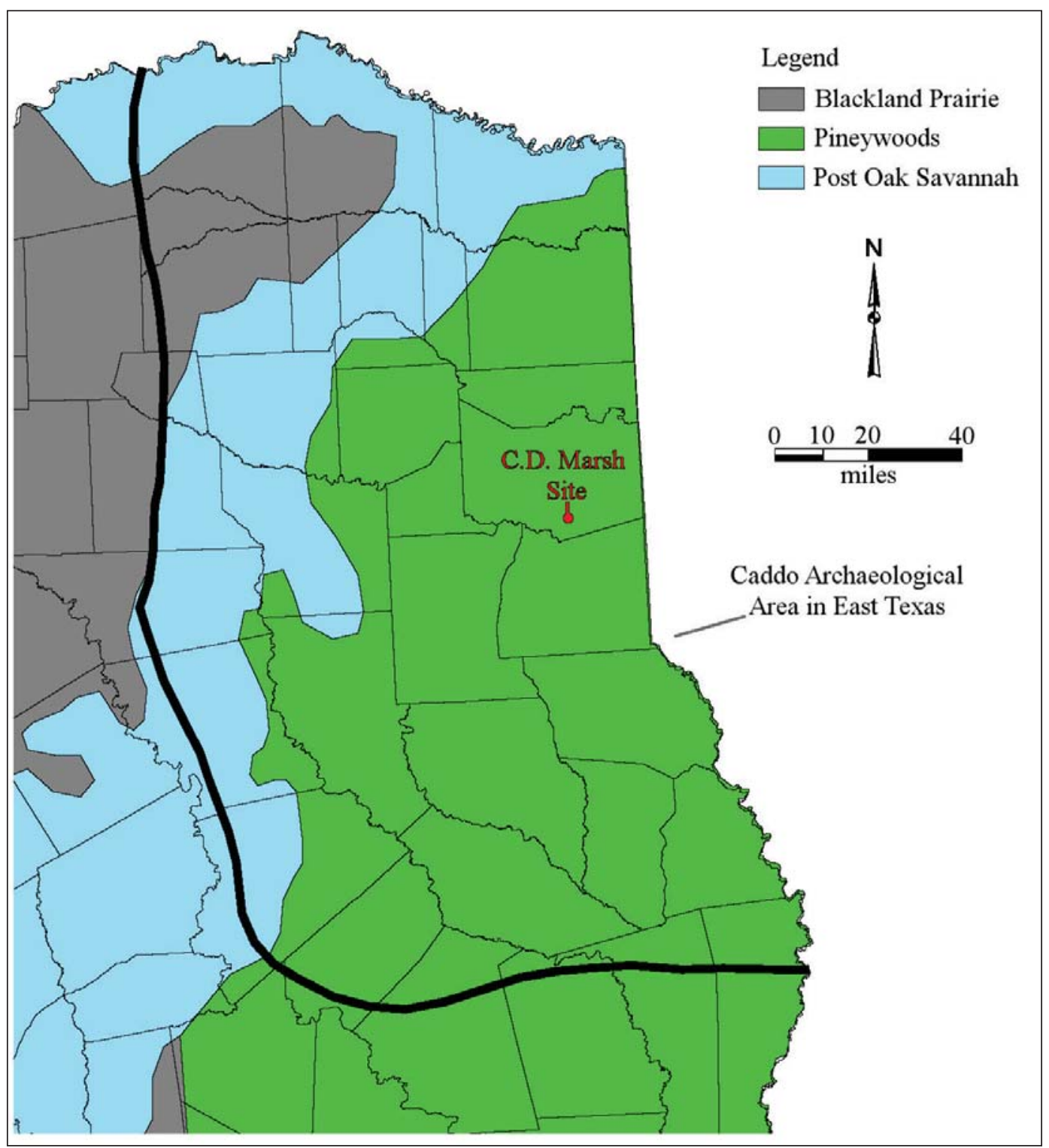

Figure 1. The location of the C. D. Marsh site (41HS269) in East Texas. 
Buddy Calvin Jones discovered the site in January 1958, and he estimated that the habitation area covered ca. 1-2 acres, with substantial midden deposits (Jones 1968:86). Jones collected a substantial sample of plain and decorated ceramic vessel sherds ( $\mathrm{n}=1736)$ from the habitation deposits (Jones 1968:96), in addition to a number of ceramic vessels and other funerary offerings from Caddo burial features. A subset of this reported sherd assemblage has been identified in the collections of the Gregg County Historical Museum, and the 2015 analysis of that sherd sample is the subject of this article.

\section{Archaeological Setting}

A total of at least eight burials were excavated at the C. D. Marsh site on Eight Mile Creek by Jones in 1959-1960 (Figure 2), including Burial 1, an historic (dating after ca. A.D. 1685) Caddo period burial (Jones 1968:89). The six ceramic vessels in Burial 1 included two Emory Punctated-Incised jars, a La Rue Neck Banded jar, one Simms Engraved carinated bowl, a small Natchitoches Engraved bottle, a Natchitoches Engraved carinated bowl, and a large plain jar (Jones 1968:Plate 16a-g); European trade goods found with this burial included two small silver disks. The other burials (Burials 2-8) are apparently part of an earlier Caddo cemetery that is thought to be associated with the ca. A.D. 1350-17 $7^{\text {th }}$ century Pine Tree Mound community along the Sabine River and its tributaries (Fields and Gadus 2012:663 and Figure 9.10). Jones (1968:85) suggested that these latter burials are from a ca. A.D. 1200-1500 Caddo cemetery.

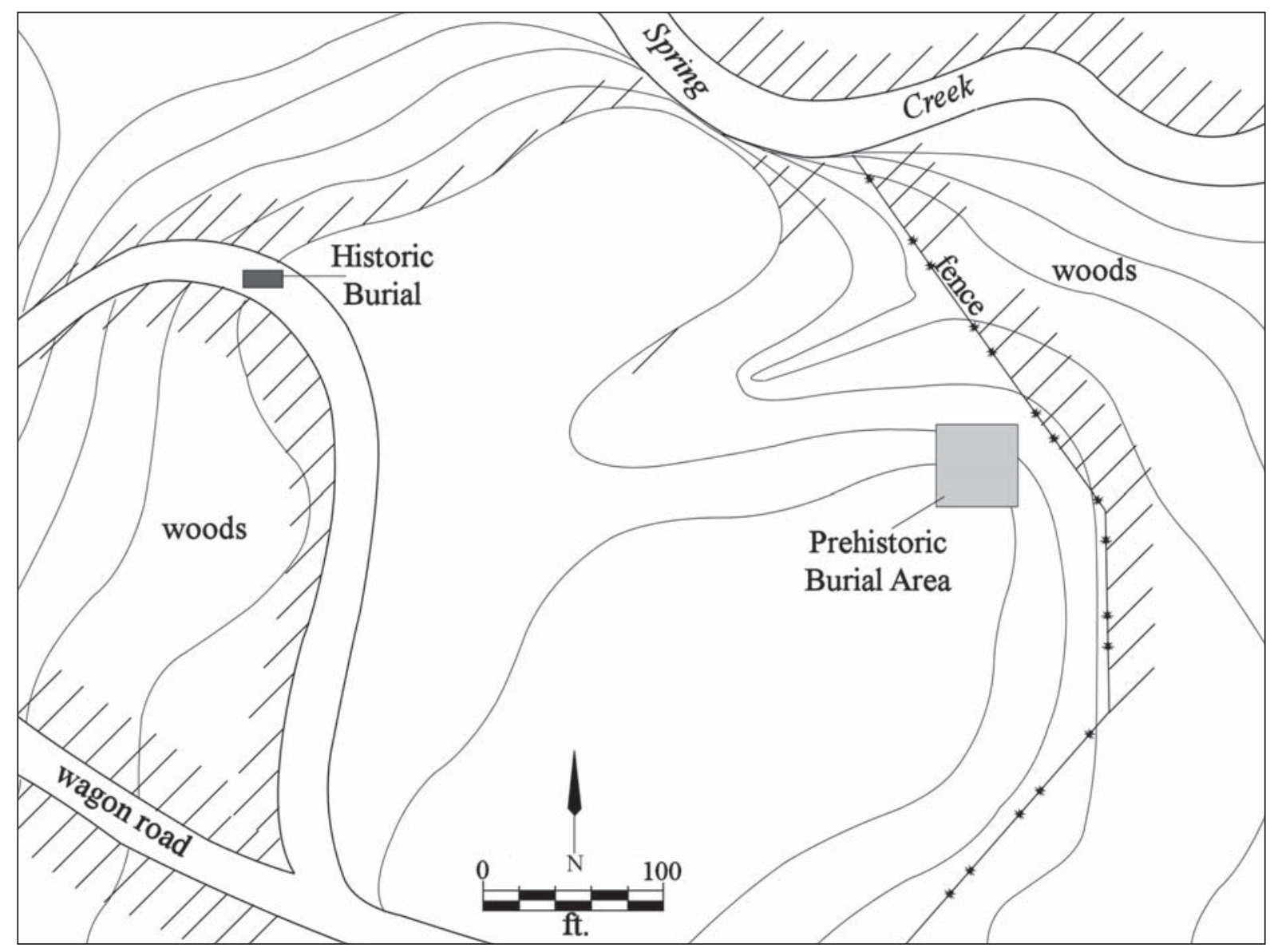

Figure 2. Map of the C. D. Marsh site and the locations of the Historic Caddo burial (Burial 1) and the prehistoric burial area.

There are a total of six ceramic vessels from the ca. A.D. 1200-1500 burials at the site that are unassociated funerary objects in the Gregg County Historical Museum collections. This includes one vessel each from Burials 5 and 8; the provenience of the other vessels at the site is unknown. The vessels 
represented include a grog-tempered Pennington Punctated-Incised carinated bowl; another grog-tempered carinated bowl with a continuous engraved scroll motif; a Maydelle Incised grog-tempered carinated bowl; a grog-tempered Pease Brushed-Incised jar; and a grog- and bone-tempered horizontal engraved bowl (Perttula et al. 2014:Figures 81, 83-86).

According to Jones (1968:Figure 6) and notes on file at the museum, these burials are located ca. 120 $\mathrm{m}$ east-southeast from the one Historic Caddo burial at the site (see Figure 2). The burials were placed in extended supine position in north-south oriented pits in three rows (Figure 3), with the head of the deceased at the southern end of the burial and facing north. The location of Burials 7 and 8 relative to the other burials is unknown. Funerary offerings included ceramic vessels and mussel shells.

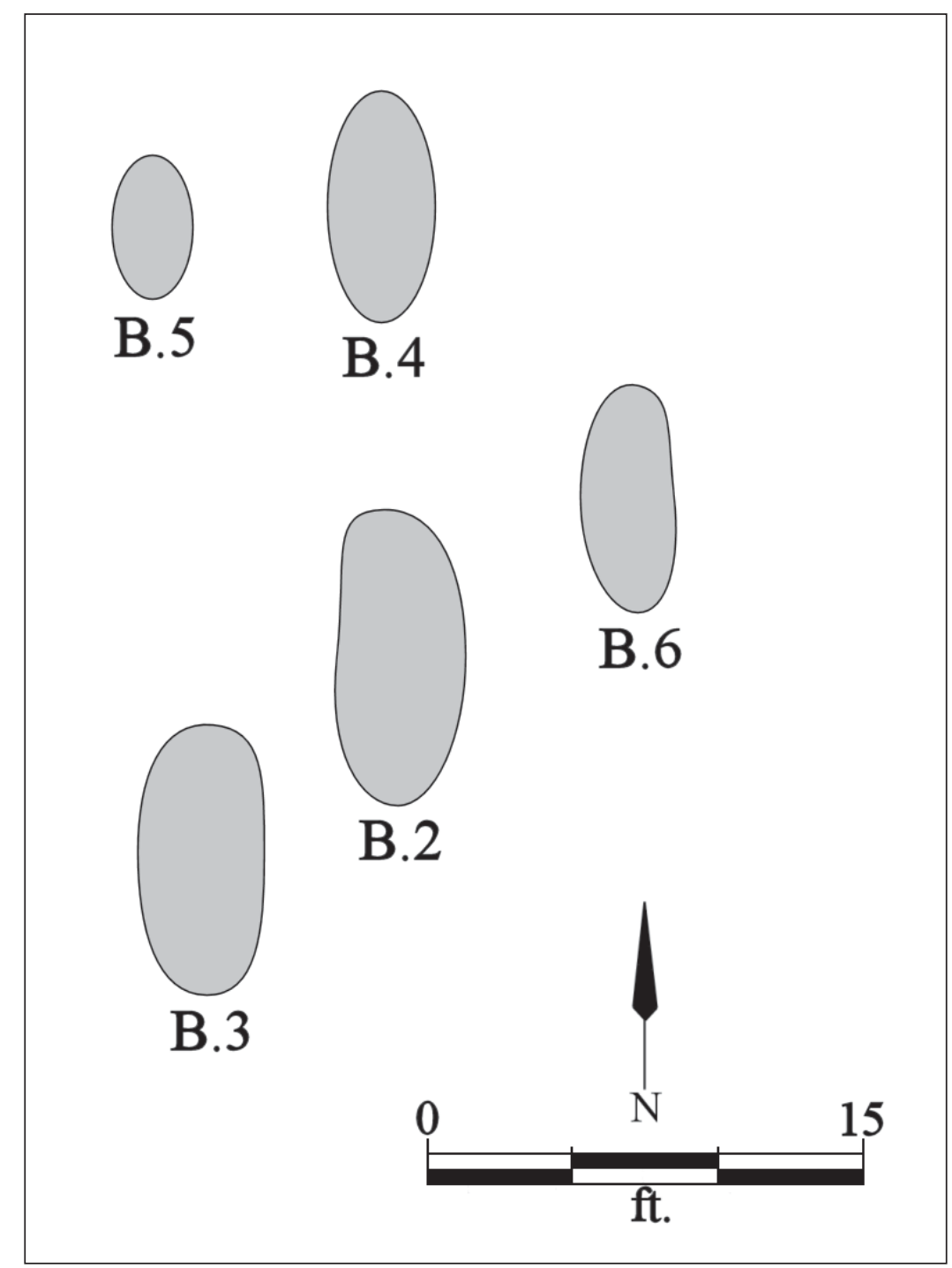

Figure 3. Plan map of Burials 2-6 at the C. D. Marsh site.

One of the unassociated ceramic vessels at the C. D. Marsh site is a Ripley Engraved, var. McKinney carinated bowl (Perttula et al. 2014:Figure 82). Such vessels would not be expected in a ca. A.D. 1200-1500 Caddo cemetery, and although this type of fine ware is commonly seen on post-A.D. 1600 Titus phase sites in the region, it is rarely found in association with European trade goods. Therefore, it may represent a burial from a third temporal component (ca. A.D. 1600-1685) at the site. 


\section{Ceramic Sherd Assemblage}

The present ceramic vessel sherd assemblage from the C. D. Marsh site is comprised of 634 plain and decorated sherds (Table 1). About 73 percent of the sherds are from grog-tempered vessels and the remainder are from bone-tempered vessels. The highest percentage of bone-tempered sherds are in the utility wares (34 percent), and brushed bone-tempered vessels are quite common in the assemblage; only 19 percent of the fine ware sherds are from bone-tempered vessels.

Table 1. Ceramic vessel sherd assemblage from the C. D. Marsh site (41HS269).

\begin{tabular}{lccc}
\hline Ware & Grog-tempered & Bone-tempered & $\mathrm{N}$ \\
\hline Plain & 213 & 52 & 265 \\
Utility & 217 & 110 & 327 \\
Fine & 34 & 8 & 42 \\
\hline Totals & 464 & 170 & 634 \\
\hline
\end{tabular}

The plain to decorated sherd ratio (P/DR) in the C. D. Marsh site assemblage is 0.72 ; this is not much different than the P/DR of 0.84 for the larger sherd assemblage reported by Jones (1968:96) from the site. Of the 369 decorated sherds, about 89 percent are from utility ware vessels, and only 11.4 percent of the sherds are from fine ware vessels (see Table 1).

There are a wide variety of decorative methods and decorative elements represented in the utility ware sherds from the C. D. Marsh site (Table 2). About 58 percent of the sherds - and 35 percent of the utility ware rim sherds - are from vessels with brushing marks, and another 16.5 percent have brushed decorative elements in combination with either appliqued, appliqued-punctated, incised, or punctated decorative elements; 20 percent of the rim sherds are from these vessels. Another 17.1 percent of the utility ware vessels - and 30 percent of the utility ware rim sherds-have incised decorative elements. Tool and fingernail punctated sherds represent 3.7 percent of the utility ware sherd assemblage, as well as 15 percent of the utility ware rims. The other decorative methods represented in the C. D. Marsh utility ware sherds are appliqued ( 0.3 percent), appliqued-incised $(0.3$ percent), incised-punctated $(2.1$ percent $)$, incisedpunctated-appliqued ( 0.3 percent), pinched ( 0.9 percent), and ridged-brushed ( 0.3 percent) (Table 2$)$.

Table 2. Decorative methods and elements in the utility ware sherds from the C. D. Marsh site (41HS269).

\begin{tabular}{|c|c|c|c|}
\hline $\begin{array}{l}\text { Decorative method/ } \\
\text { Decorative element }\end{array}$ & Rim & Body & $\mathrm{N}$ \\
\hline \multicolumn{4}{|l|}{ Appliqued } \\
\hline straight appliqued ridge & - & 1 & 1 \\
\hline \multicolumn{4}{|l|}{ Appliqued-Incised } \\
\hline straight appliqued ridge and straight incised line & - & 1 & 1 \\
\hline \multicolumn{4}{|l|}{ Brushed } \\
\hline horizontal brushed & 6 & - & 6 \\
\hline overlapping brushed & - & 8 & 8 \\
\hline parallel brushed & - & 175 & 175 \\
\hline vertical brushed & 1 & 1 & 2 \\
\hline
\end{tabular}


Table 2. Decorative methods and elements in the utility ware sherds from the C. D. Marsh site (41HS269), cont.

Decorative method/ Rim Body N

Decorative element

Brushed-Appliqued

diagonal brushed and straight appliqued fillet

opposed brushed and straight appliqued ridge

parallel brushed and straight appliqued fillet

parallel brushed and straight appliqued ridge

vertical brushing and vertical appliqued ridge

$\begin{array}{lll}- & 2 & 2 \\ - & 1 & 1 \\ - & 9 & 9 \\ - & 3 & 3 \\ - & 1 & 1 \\ & & \\ 1 & - & 1 \\ & & \\ & & \\ 1 & & 1 \\ - & - & 18 \\ - & 18 & 5\end{array}$

Brushed-Appliqued-Punctated

horizontal brushed rim, vertical appliqued ridge on body, vertical brushed body, and linear punctated row below rim-body juncture

\section{Brushed-Incised}

horizontal brushed on rim and vertical brushed-incised on body parallel brushed-incised marks and lines parallel brushed and overlying parallel incised lines

\section{Brushed-Punctated}

diagonal brushed and tool punctated row under lip horizontal brushed and tool punctated row under lip parallel brushed and fingernail punctated row through the brushing parallel brushed and tool punctated row through the brushing tool punctated row and diagonal brushed on body tool punctated row above horizontal brushing tool punctated row above vertical brushing

\section{Incised}

curvilinear line diagonal lines

diagonal and vertical lines

diagonal lines and hatched zone

diagonal opposed lines

horizontal lines

opposed lines

parallel lines

parallel and cross-hatched lines

straight line

\section{Incised-Punctated}

curvilinear incised zone filled with circular punctations curvilinear incised line and adjacent tool punctated row

$\begin{array}{lll}1 & - & 1 \\ 1 & - & 1 \\ - & 1 & 1 \\ - & 7 & 7 \\ - & & \\ - & 1 & 1 \\ - & 1 & 1\end{array}$

1
7
1
1
1

$\begin{array}{lll}- & 1 & 1 \\ 1 & 1 & 2 \\ 1 & - & 1 \\ 2 & 1 & 3 \\ - & 3 & 3 \\ 2 & - & 2 \\ - & 9 & 9 \\ - & 28 & 28 \\ - & 2 & 2 \\ - & 5 & 5\end{array}$

$\begin{array}{lll}- & 1 & 1 \\ - & 1 & 1\end{array}$


Table 2. Decorative methods and elements in the utility ware sherds from the C. D. Marsh site (41HS269), cont.

\begin{tabular}{llll}
\hline $\begin{array}{l}\text { Decorative method/ } \\
\text { Decorative element }\end{array}$ & Rim & Body & N \\
\hline $\begin{array}{l}\text { parallel lines and adjacent tool punctated zone } \\
\text { triangular incised zone filled with tool punctates }\end{array}$ & - & 4 & 4 \\
$\begin{array}{l}\text { Incised-Punctated-Appliqued } \\
\text { opposed incised lines and tool punctated zones, and } \\
\text { straight appliqued fillet }\end{array}$ & - & 1 & 1 \\
$\begin{array}{l}\text { Pinched } \\
\text { parallel pinched ridges }\end{array}$ & - & 3 \\
$\begin{array}{l}\text { Punctated } \\
\text { fingernail punctated row } \\
\text { tool punctated row under the lip } \\
\text { tool punctated rows }\end{array}$ & - & 3 & 1 \\
$\begin{array}{l}\text { Ridged-Brushed } \\
\text { straight ridge and parallel brushed }\end{array}$ & 1 & 1 & 1 \\
\hline \begin{tabular}{l} 
Totals \\
\hline
\end{tabular} & 2 & 8 & 10 \\
\hline
\end{tabular}

The appliqued and appliqued-incised sherds are from jars that likely have vertical appliqued ridges and vertical appliqued ridges-incised lines on the vessel body (see Table 2). These would have divided the vessel body into panels that were either plain or were filled with incised lines; the latter is likely from a Pease Brushed-Incised vessel (see Suhm and Jelks 1962:119).

The brushed sherds in the C. D. Marsh sherd assemblage are from Bullard Brushed jars with horizontal or vertical brushing marks on the rim and overlapping or vertical brushing marks on the vessel body (see Table 2). The frequency of brushed utility ware sherds at the site is notable, and the proportions of brushed sherds suggest that the main ancestral Caddo occupation of the settlement at the C. D. Marsh site occurred after ca. A.D. 1450 (Perttula 2014:31 and Table 13).

The brushed-appliqued, brushed-incised, brushed-punctated, and brushed-punctated-appliqued (Figure 4a) sherds (see Table 2) are from Maydelle Incised, Pease Incised-Brushed, or Bullard Brushed jars. These have brushed rims, and various appliqued, incised, or punctated elements on the vessel body in conjunction with brushed background elements.

Most of the sherds from incised vessels have simple parallel or opposed lines, while rims and body sherds from Maydelle Incised vessels have diagonal lines, diagonal and vertical lines, diagonal lines and a hatched zone (see Figure 4b-f), diagonal opposed lines, and horizontal lines. Only one of the incised sherds does not have a straight line or geometric decorative element (see Table 2).

The incised-punctated utility ware sherds have triangular or curvilinear incised zones filled with tool punctations (see Figure 4g and Table 2); these are probably from Maydelle Incised jars (see Suhm and Jelks 1962:103). One body sherd has opposed incised lines that divide two tool punctated zones, and there is a straight appliqued fillet paralleling one of the incised lines (see Figure 4h). 

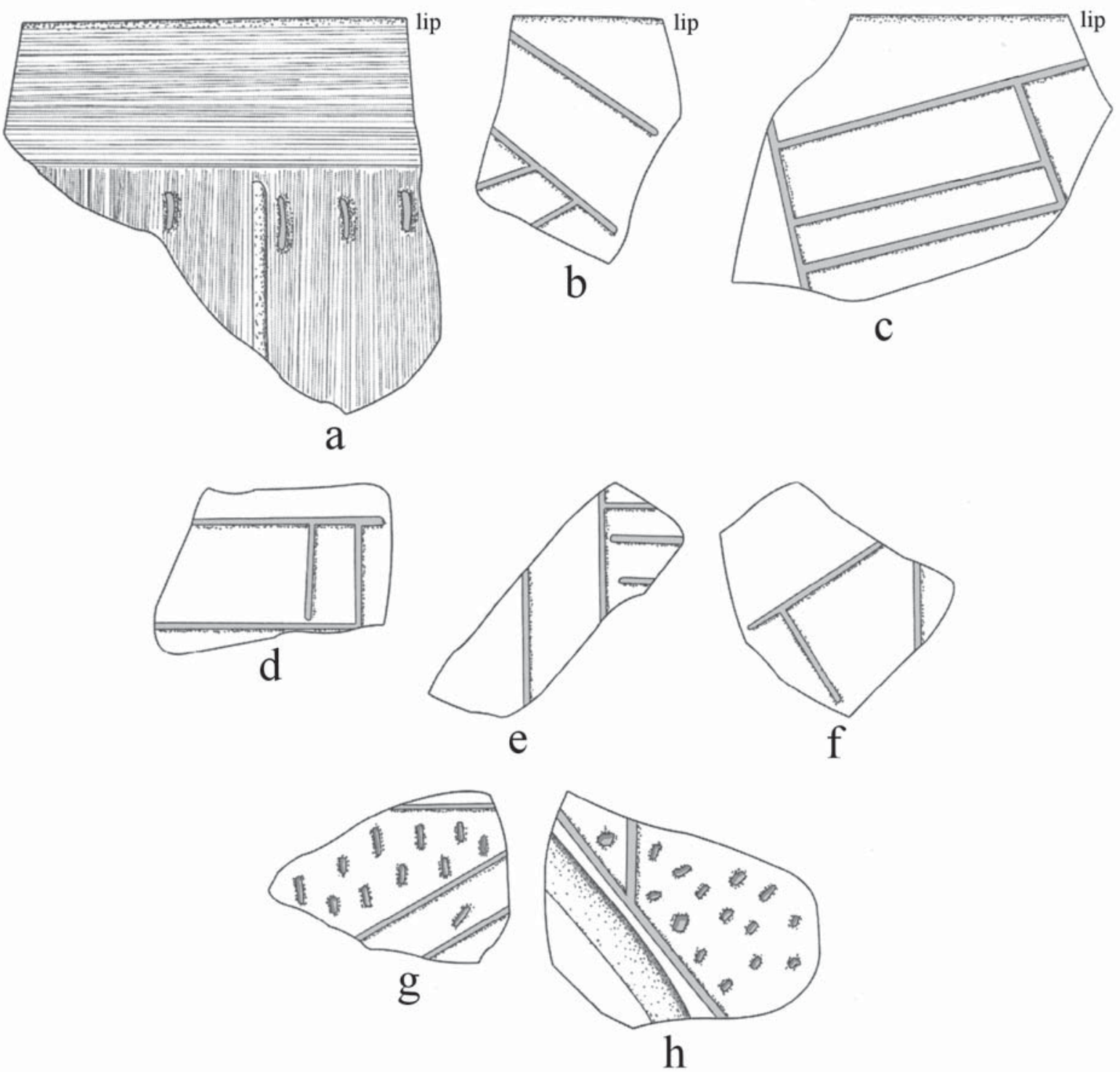

Figure 4. Selected decorative elements represented in the utility ware sherds from the C. D. Marsh site (41HS269): a, brushed-appliqued-punctated rim; b-c, e, incised rim sherds; d, f, incised body sherds; g, incised-punctated body sherd; h, incised-appliqued-punctated body sherd.

Three body sherds from Killough Pinched jars have parallel rows of pinched ridges (see Table 2). Over 90 percent of the utility ware sherds with punctated elements have rows of tool punctations on the rim and/ or body. Only one body sherd has a row of fingernail punctations.

The one ridged-brushed body sherd in the C. D. Marsh site collection is from a Belcher Ridged, var. Byram Ferry vessel. This is a $15^{\text {th }}$ century A.D. utility ware likely made by a Caddo potter along the Red River (Girard 2007).

The fine ware sherds from the C. D. Marsh site in the Gregg County Historical Museum collections are from engraved vessels (Table 3), all from carinated bowls or bowls; no bottle sherds were identified in the assemblage. About 5 percent of these sherds are from vessels that also have an ochre-rich red slip added to the interior and exterior vessel surfaces. Only one engraved sherd (2.4 percent of the fine wares) has evidence of a red clay pigment that had been rubbed in the engraved decorative element. 
Table 3. Decorative methods and elements in the fine ware sherds from the C. D. Marsh site (41HS269).

\begin{tabular}{llll}
\hline $\begin{array}{l}\text { Decorative method/ } \\
\text { Decorative element }\end{array}$ & Rim & Body & N \\
\hline Engraved & & $3 *$ & 3 \\
cross-hatched zone & - & 3 & 3 \\
curvilinear lines & - & 1 & 1 \\
curvilinear hatched zone & - & 3 & 3 \\
diagonal lines & - & 1 & 1 \\
excised zone, narrow & - & 2 & 3 \\
hatched zone & 1 & - & 3 \\
horizontal lines & 3 & 1 & 1 \\
horizontal line with tick marks & - & 1 & 1 \\
horizontal and diagonal lines & - & 1 & 3 \\
horizontal, vertical, and curvilinear lines & - & 3 & 1 \\
parallel lines & - & 1 & 1 \\
parallel and diagonal lines & - & 1 & 1 \\
slanted scroll lines & - & 14 & 1 \\
straight line & - & 1 & 1 \\
straight line with tick marks & - & 1 & 42 \\
Engraved-Red-Slipped & & 38 & \\
straight line and int./ext. red-slipped & - & & 1 \\
hatched zone and int./ext. red-slipped & - & 4 & 1 \\
\hline Totals & & & 1 \\
\hline
\end{tabular}

*one sherd with red pigment rubbed in engraved lines

The few rim sherds from fine ware vessels have either equally-spaced horizontal engraved lines or a hatched zone (Figure 5c); one body sherd has a curvilinear hatched zone (Figure 5d). One lower rim sherd from a carinated bowl has a Ripley Engraved slanting scroll decorative element (Figure 5a), and two sherds are from Simms Engraved carinated bowls: they have straight or horizontal engraved lines with small excised tick marks (Figure 5f). There is also a lower rim sherd from a Poynor Engraved vessel, probably var. Blackburn (Perttula 2011:Figure 6-64b): this has closely-spaced horizontal, vertical, and curvilinear decorative elements (Figure 5e).

As previously mentioned, two of the engraved sherds in the C. D. Marsh sherd assemblage have interior and exterior red-slipped surfaces (see Table 3). One of these sherds simply has a single straight engraved line, while the other has an engraved hatched zone (see Figure $5 b$ ). 

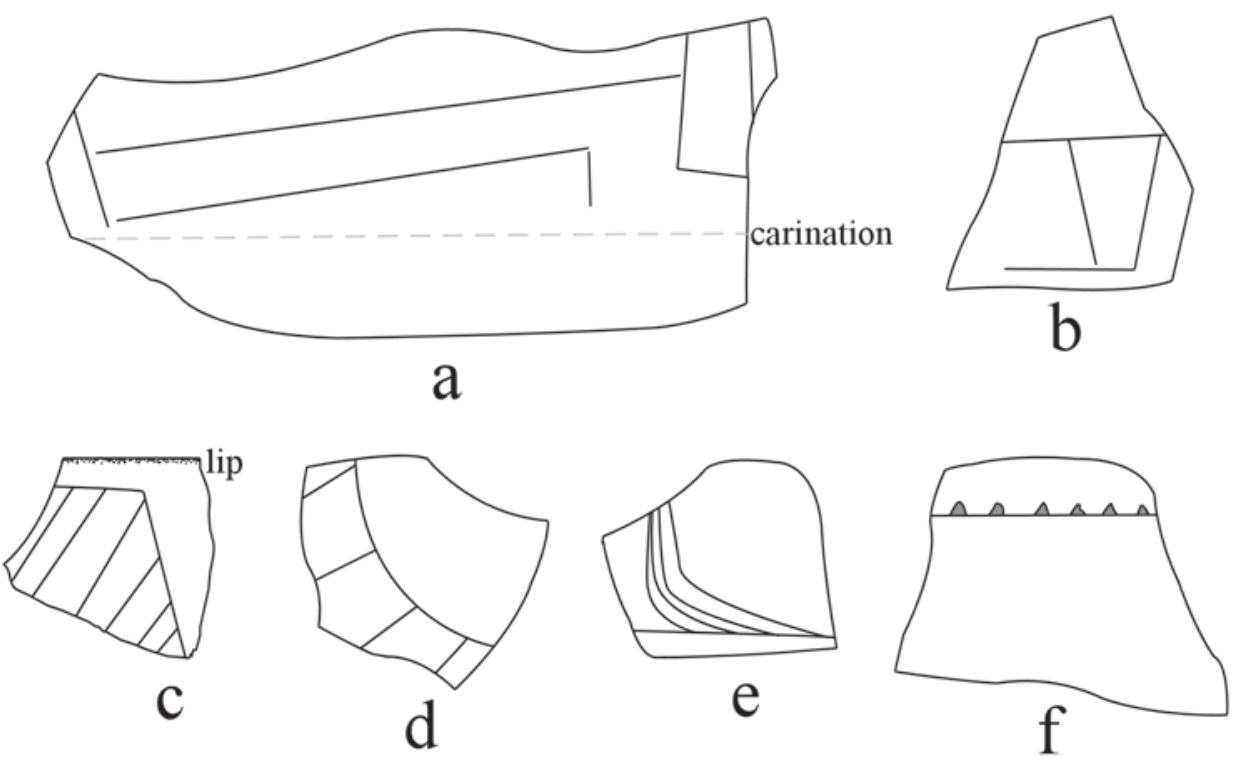

Figure 5. Selected decorative elements represented in the fine ware sherds from the C. D. Marsh site (41HS269): a, engraved carinated bowl sherd; b, engraved-red-slipped body sherd; c, engraved rim sherd; d-e, engraved body sherds; f, Simms Engraved carinated bowl sherd.

\section{SUMMARY AND CONCLUSIONS}

The C. D. Marsh site (41HS269) is a Caddo settlement and cemetery on Eight Mile Creek, a tributary to the Sabine River that was discovered in 1958 by Buddy Calvin Jones. One occupation of the site took place in historic times, after ca. A.D. 1685, based on the recovery of Natchitoches Engraved vessels and two silver disks from one burial. The majority of the ancestral Caddo occupation took place after ca. A.D. 1450, based on the identification of several Late Caddo period fine ware types (including Ripley Engraved, Poynor Engraved, and Simms Engraved), a $15^{\text {th }}$ century Belcher Ridged, var. Byram Ferry sherd, and the overall proportion of brushed sherds from utility ware vessels in the assemblage: 66.4 percent of all the decorated sherds from the C. D. Marsh site have brushed decorative elements. None of the utility ware and fine ware sherds in the site ceramic assemblage can be definitely associated with a post-A.D. 1685 Kinsloe phase Caddo occupation.

The archaeological investigations at the C. D. Marsh site resulted in the collection of a large assemblage of decorated utility ware and fine ware rim and body sherds $(n=369)$ from habitation deposits there. The stylistic character of these sherds is useful in assessing the age of the Caddo occupation at the site, and in outlining the historical relationships evidenced in the decorative elements and motifs that speak of cultural transmission and stylistic change and continuity in the decoration of Caddo vessels in the mid-Sabine River basin.

The ceramic sherd assemblage is predominantly from grog-tempered vessels ( 73 percent); the remainder are from bone-tempered vessels. There are 24 rim sherds from utility ware and fine wares in the ceramic assemblage, and 83 percent are from utility ware vessels.

More than 88 percent of the decorated sherds from the C. D. Marsh site are from utility ware vessels $(n=327)$; fine wares (sherds with engraved and engraved-red-slipped decorative elements) comprise only 11.4 percent of the decorated sherd assemblage. 
Among the decorated utility ware rim sherds, decorative methods and elements include punctated (primarily rows of tool punctations), incised-punctated (from Maydelle Incised jars), incised (most from Maydelle Incised vessels), brushed (from Bullard Brushed jars), and brushed-punctated (also probably from Bullard Brushed jars) decorative elements. Other utility wares include a number of sherds from Pease Brushed-Incised vessels, Killough Pinched jar sherds, and one Belcher Ridged, var. Byram Ferry sherd.

The fine ware sherds from the C. D. Marsh site include rims from engraved carinated bowls and bowls. They feature rims with horizontal lines and various associated elements or a rim with a rectangular hatched zone. One of the rims has a scroll element, which feature so prominently in post-ca. A.D. 1450 assemblages in the mid-Sabine River basin (e.g., Fields and Gadus 2012).

In conclusion, the utility ware and fine ware sherds from the C. D. Marsh site in the Gregg County Historical Museum collections are stylistically similar to the post-A.D. 1450 ceramic vessel sherds documented from the Pine Tree Mound community (see Fields and Gadus 2012) a few miles to the northwest on another tributary of the Sabine River, as well as to other sites in the area (Perttula 2014:Table 13). It is likely that these stylistic similarities are indicative of the fact that various Caddo communities in this part of the Sabine River basin had close social and cultural ties and established networks of contact and cultural transmission of ideas and practices.

\section{ACKNOWLEDGMENTS}

Thanks to Lance Trask for preparing the figures for this article.

\section{REFERENCES CITED}

Fields, R. C. and E. F. Gadus (editors)

2012 Archeology of the Nadaco Caddo: The View from the Pine Tree Mound Site (41HS15), Harrison County, Texas. 2 Vols. Reports of Investigations No. 164. Prewitt and Associates, Inc., Austin.

Girard, J. S.

2007 Byram Ferry (16BO17): A Middle to Late Caddo Period Mound Site in the Red River Floodplain, Northwest Louisiana. Caddo Archeology Journal 16:9-25.

Jones, B. C.

1968 The Kinsloe Focus: A Study of Seven Historic Caddoan Sites in Northeast Texas. Master's thesis, Department of Anthropology, University of Oklahoma, Norman.

Perttula, T. K.

2011 The Ceramic Artifacts from the Lang Pasture Site (41AN38) and the Place of the Site Within an Upper Neches River Basin Caddo Ceramic Tradition. In Archeological Investigations at the Lang Pasture Site (41AN38) in the Upper Neches River Basin of East Texas, assembled and edited by T. K. Perttula, D. B. Kelley, and R. A. Ricklis, pp. 145-320. Report 129, Texas Department of Transportation, Archeological Studies Program, Environmental Affairs Division, Austin.

2014 The Caddo Archaeology of the Musgano Site (41RK19) in the Sabine River Basin of East Texas. Special Publication No. 28. Friends of Northeast Texas Archaeology, Pittsburg and Austin.

Perttula, T. K., R. Z. Selden, Jr., and B. Nelson

2014 Documentation of Unassociated Ceramic Vessel Funerary Objects in the Gregg County Historical Museum Collections from Sites in Gregg, Harrison, and Panola Counties in East Texas. Special Publication No. 29. Friends of Northeast Texas Archaeology, Austin and Pittsburg.

Suhm, D. A. and E. B. Jelks (editors)

1962 Handbook of Texas Archeology: Type Descriptions. Special Publication No. 1, Texas Archeological Society, and Bulletin No. 4, Texas Memorial Museum, Austin. 